\title{
Twist-Related Protein 1
}

National Cancer Institute

\section{Source}

National Cancer Institute. Twist-Related Protein 1. NCI Thesaurus. Code C39918.

Twist-related protein 1 (202 aa, $21 \mathrm{kDa}$ ) is encoded by the human TWIST 1 gene. This protein plays a role in the negative regulation of both transcription and myogenesis. 